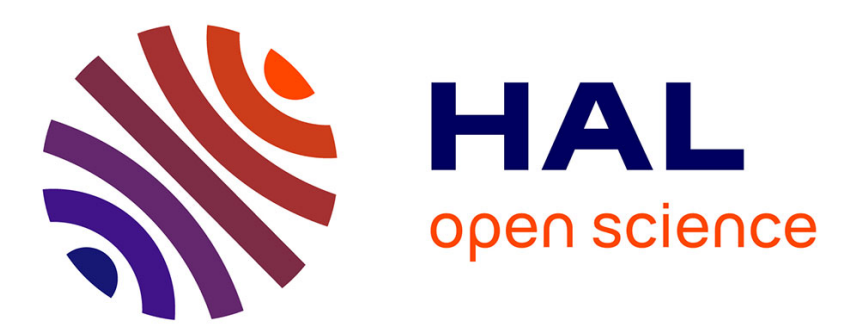

\title{
Interaction between trench retreat and anatolian escape as recorded by neogene basins in the northern Aegean Sea
}

Anouk Beniest, Jean-Pierre Brun, Christian Gorini, Vincent Crombez, Rémi Deschamps, Youri Hamon, Jeroen Smit

\section{To cite this version:}

Anouk Beniest, Jean-Pierre Brun, Christian Gorini, Vincent Crombez, Rémi Deschamps, et al.. Interaction between trench retreat and anatolian escape as recorded by neogene basins in the northern Aegean Sea. Marine and Petroleum Geology, 2016, 77, pp.30-42. 10.1016/j.marpetgeo.2016.05.011 . insu-01321131

\section{HAL Id: insu-01321131 \\ https://hal-insu.archives-ouvertes.fr/insu-01321131}

Submitted on 25 May 2016

HAL is a multi-disciplinary open access archive for the deposit and dissemination of scientific research documents, whether they are published or not. The documents may come from teaching and research institutions in France or abroad, or from public or private research centers.
L'archive ouverte pluridisciplinaire HAL, est destinée au dépôt et à la diffusion de documents scientifiques de niveau recherche, publiés ou non, émanant des établissements d'enseignement et de recherche français ou étrangers, des laboratoires publics ou privés. 


\section{Accepted Manuscript}

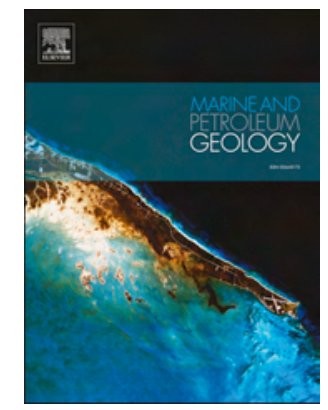

Interaction between trench retreat and anatolian escape as recorded by neogene basins in the northern Aegean Sea

A. Beniest, J.P. Brun, C. Gorini, V. Crombez, R. Deschamps, Y. Hamon, J. Smit

PII:

S0264-8172(16)30150-7

DOI:

10.1016/j.marpetgeo.2016.05.011

Reference:

JMPG 2557

To appear in: $\quad$ Marine and Petroleum Geology

Received Date: 13 January 2016

Accepted Date: 9 May 2016

Please cite this article as: Beniest, A., Brun, J.P., Gorini, C., Crombez, V., Deschamps, R., Hamon, Y., Smit, J., Interaction between trench retreat and anatolian escape as recorded by neogene basins in the northern Aegean Sea, Marine and Petroleum Geology (2016), doi: 10.1016/j.marpetgeo.2016.05.011.

This is a PDF file of an unedited manuscript that has been accepted for publication. As a service to our customers we are providing this early version of the manuscript. The manuscript will undergo copyediting, typesetting, and review of the resulting proof before it is published in its final form. Please note that during the production process errors may be discovered which could affect the content, and all legal disclaimers that apply to the journal pertain. 


\title{
Interaction between trench retreat and Anatolian escape as
}

\section{recorded by Neogene basins in the northern Aegean Sea}

\author{
Beniest, A. ${ }^{1,2}$, Brun, J.P. ${ }^{3}$, Gorini, C. ${ }^{1}$, Crombez, V. ${ }^{1,2}$, Deschamps, R. ${ }^{2}$, Hamon, Y. ${ }^{2}$, \\ Smit, $\mathbf{J}^{4}$ \\ 1. Sorbonne Universités, ISTeP UPMC, Paris, France, CNRS UMR 7193, Université \\ Pierre et Marie Curie, Paris CEDEX, France \\ 2. IFPEN, 1-4 Avenue de Bois-Préau, 92852 Rueil-Malmaison Cedex, France \\ 3. Géosciences Rennes, UMR 6118 CNRS, Université Rennes1, Campus de Beaulieu, \\ 35042 Rennes, France
}

4. Department of Earth Sciences, Utrecht University, Utrecht, Netherlands

\section{To be submitted to}

\section{Marine and Petroleum Geology}

\begin{abstract}
The evolution of the North Aegean Sea is studied through the development of three deep basins: the North Aegean Trough, the North Skyros Basin and the Ikaria Basin. Bathymetric data, a 2D seismic dataset and the well-investigated stratigraphic records of the onshore deep basins of northern Greece and Western Turkey were used to make structural and seismic stratigraphic interpretations. The study area shows two sharp unconformities that correspond to the Eocene-Oligocene transition and the Miocene-Pliocene shift. These discontinuities were used as marker horizons for a more detailed structural and seismic
\end{abstract}


stratigraphic interpretation resulting in the identification of several seismic units. A general seismic signature chart was established using onshore basin stratigraphy and well data, which was then used to constrain the ages of the different seismic units. The main features observed in the basins are interpreted as: 1) trans-tensional growth patterns in Pliocene and Quaternary sediments that combine NE-SW trending and steeply dipping fault zones that likely correspond to strike-slip corridors and E-W/WNW-ESE trending normal faults, 2) regional erosional truncations of Miocene sediments, likely related to the Messinian Salinity Crisis (MSC), 3) thick delta-turbidite deposits of Neogene age. Only the North Aegean Trough shows evidence of earlier development and polyphase deformation through inversion structures, and additional seismic units. Extension processes in the Aegean region have been driven by the Hellenic slab rollback since the middle Eocene. The widespread development of Neogene basins at the whole Aegean scale attests to a major tectonic change due to an acceleration of the trench retreat in the middle Miocene. The present study shows that the Neogene basins of the North Aegean Sea developed in dextral transtension with the northward migration of the associated NE-SW trending strike-slip faults. At regional scale, this tectonic pattern indicates that the westward escape of Anatolia started to interact with the trench retreat in the middle Miocene, around 10 Myr before the arrival of the North Anatolian Fault in the North Aegean Sea.

\section{Introduction}

The first plate kinematic models of the eastern Mediterranean (McKenzie, 1972; Le Pichon and Angelier, 1981) and the present-day displacement field observed by satellite geodesy (McClusky et al., 2000; Hollenstein et al., 2008; Müller et al., 2013) show that the active Aegean extension results from the combined effects of the southwestward retreat of the Hellenic trench and the westward displacement of Anatolia along the North Anatolian Fault 
(NAF). The geological record shows that this interaction between two strongly oblique components of boundary displacement started in the middle Miocene (Dewey and Sengör, 1979; Şengör et al., 2005; Philippon et al., 2014), around 10 My before the NAF reached the Aegean (Armijo et al., 1999; Hubert-Ferrari et al., 2003; Şengör et al., 2005). On the other hand, the coeval extensional exhumation of high-pressure metamorphic rocks in the southern Hellenides and high-temperature metamorphic rocks in the Southern Rhodope (Brun and Sokoutis, 2007; Brun and Faccenna, 2008) started in the middle Eocene (see review of data in Jolivet and Brun, 2010; Philippon et al., 2012). This brief summary of the Aegean extension history, which occurred during a large part of the Tertiary, shows that Aegean extension was not continuous, either in time or in space, but that it occurred in two major stages (Philippon et al., 2014; Brun et al., 2015). This is evidenced by a striking difference in the distribution of Paleogene and Neogene sedimentary basins in the Aegean region. This suggests that a major change in the dynamics of Aegean extension happened in the middle Miocene, more than 30 My after its onset.

In the present paper, we first evaluate offshore and onshore stratigraphy in the northern Aegean Sea (Fig 1.) from onshore basins described in the literature, available well logs and published offshore studies. We compare basin infill characteristics with the seismic stratigraphic interpretation of two lines in the Thermaikos and Prinos basins. Then, on this basis and using a 2D seismic data set, we describe the structure and seismic stratigraphy of the North Aegean Trough, the North Skyros Basin and the Ikaria Basin. These data are then used to discuss the regional geodynamic setting and, in particular, the interaction between trench retreat and Anatolian escape

\section{The project database}


Only a few seismic reflection studies of the offshore northern Aegean domain have been published. The most extensive structural and stratigraphic work using seismic reflection data was done by Martin (1987) and Mascle and Martin (1990). Lykousis (2009), Lykousis et al. (1995, 2002, 2005) and Brooks and Ferentinos (1980) used shallow seismic reflection data, with a focus on seismic facies and depositional environments of mainly Quaternary deposits. Deep seismic stratigraphic descriptions are not available for the northern Aegean Sea.

The database used for this study is a compilation of 1) a $2 \mathrm{D}$ seismic reflection dataset acquired in the 1970s by Texaco, SEISA and ENSPM; 2) published seismic reflection data; 3) GMRT bathymetric data (Ryan et al., 2009); 4) well data provided by TOTAL. The lines cover an area of roughly $70 \mathrm{~km}^{2}$ with line spacing of between 1 and $20 \mathrm{~km}$. The lines vary in length from $1.5 \mathrm{~km}$ to $15 \mathrm{~km}$ and run mostly NW-SE and SW-NE. The seismic data have not been reprocessed, leaving mostly low-quality images. As only paper versions were available, lines were scanned before being digitized with MatLab, Mapviewer and Didger for SGY-file creation at the University of Pierre and Marie Curie, Paris 6. They were integrated into Petrel and Kingdom Suite projects. The maximum depth of the lines was 5 seconds two-way-travel time. In the absence of a velocity model, an average of $2500 \mathrm{~m} / \mathrm{s}$ for Tertiary deposits was assumed for the time-depth conversion, resulting in a first estimated basin depth of $6.25 \mathrm{~km}$. Published seismic reflection data in the northern Aegean domain (Schuster et al., 1987; Mascle and Martin, 1990; Roussos and Lyssimachou, 1991; Proedrou and Papaconstantinou, 2004; Nunn and Harris, 2007; Sakellariou et al., 2013) were digitized, interpreted and incorporated in our analysis. Previous work by Mascle and Martin (1990) and Brun et al. (2016) was fundamental to map fault traces at sea floor level (Fig. 1). We used the GMRT bathymetric data set (Ryan et al., 2009) in combination with the high-resolution bathymetry existing for the North Aegean Trough (Papanikolaou et al., 2002) to map the faults at the ocean floor. Where possible the pre-existing interpretation has been enhanced with the use of 
our seismic data. In-active faults are shown and depicted with dashed line, e.g. the MidCycladic Lineament (Walcott and White, 1998). Diagraphic data from eight wells including gamma ray and sonic logs for all wells were studied. Density, caliper and resistivity logs were available for only a few wells. Seismic facies were distinguished by extracting stratigraphic data from four wells (Martin, 1987).

\section{Stratigraphy of northern Aegean Tertiary basins}

Published literature provides sedimentary and stratigraphic information on the basin infill, both on- and offshore. In this study, we evaluated onshore and offshore stratigraphy based on 1) an extensive review of onshore literature, 2) eight well logs, and 3) a few published studies on the offshore realm. In this section, we compare the basin infill characteristics (Fig. 2) with the seismic stratigraphic interpretation of two lines, in the Thermaikos and Prinos basins respectively, to which two wells were tied (Fig. 3).

\subsection{Onshore basins}

To better constrain the stratigraphy of the deep north Aegean basins, we compiled data from published sources on the stratigraphy of the onshore basins surrounding the northern Aegean domain (Fig. 2): the Gulf of Saros (SB, Fig. 1) (Martin, 1987), the well-investigated Thrace Basin (TrB, Fig. 1) (Okay et al., 1996; Coskun, 2000; Turgut and Eseller, 2000; Siyako and Huvaz, 2007; Islamoglu et al., 2008; Elmas and Bentli, 2013), the Samos Basin (Sa, Fig. 1) (Weidmann et al., 1984; Deschamps et al., 2013) and the Menderes grabens (KMG, BMG, Fig. 1) (Turgut and Eseller, 2000). The oldest sedimentary rocks encountered in the surrounding onshore basins are Mesozoic metamorphosed sediments on several Cycladic islands (See Fig. 3 in Philippon et al., 2012). However, these belong to the basement of the Tertiary basins and are consequently not considered in this study. 
The oldest non-metamorphosed Tertiary sediments are observed in the Thrace Basin and the Gulf of Saros (Turgut and Eseller, 2000; Siyako and Huvaz, 2007). In these two basins, the oldest deposits are Eocene in age and generally display a complete deepening/shallowing sequence. Thus, in the Saros Basin, continental deposits are followed by shallow marine and subsequent turbidite facies that in turn, gradually become shallower, with marine offshore to shore face deposits and platform carbonates. In the Thrace Basin, the lower part of this sequence is not present, and the Eocene deposits begin directly with turbidite facies. These early deposits are only observed along the very northern margin of the Aegean Sea in the offshore basins of Prinos or Kavala Basins (Martin, 1987; Turgut and Eseller, 2000; Siyako and Huvaz, 2007; Islamoglu et al., 2008).

Onshore, Oligocene deposits are not present in the Saros Basin, but are well-developed in the Thrace Basin (Martin, 1987; Turgut and Eseller, 2000; Siyako and Huvaz, 2007; Islamoglu et al., 2008). In the Thrace Basin, they are composed of marine siliciclastic deposits, organized in small-scale prograding sequences of offshore to shoreface facies. The presence of pre-Miocene sediments has also been demonstrated in the Meso-Hellenic Basin north of the offshore Thermaikos Basin (Ferrière et al., 2004). The pre-Neogene basin infill, known from the northern margin of the northern Aegean domain, was recognized based on the identification of microfaunas in wells and outcrops (Martin, 1987; Proedrou and Papaconstantinou, 2004) but the microfaunas have never been more precisely dated than the Oligocene.

In the northern onshore basins (Thrace Basin and Saros Basin), the Miocene series comprise undifferentiated fluvial and floodplain deposits (Ferrière et al. 2004). This type of deposition continues during the Pliocene-Quaternary (Melinte-Dobrinescu et al., 2009). In the Saros Basin, the Miocene succession is less thick and probably limited to the Upper Miocene. 
In the Thrace Basin, the succession is thicker (around 1,500 m) and probably extends from the Lower to the Upper Miocene.

A major unconformity between the basement and a thick package of Upper Miocene sediments in the southern onshore basins of Samos are interpreted as a lacustrine/fluviolacustrine succession (Deschamps et al., 2013). The same applies to the Menderes grabens, in the onshore portion of Anatolia (Ersoy et al., 2014), where thick packages of fluvio-lacustrine Miocene/Pliocene-Quaternary deposits lie on a Paleozoic basement (Turgut and Eseller, 2000).

\subsection{Offshore basins}

For the offshore basin stratigraphy, we were able to tie six out of eight well logs to seismic reflection data: two in the Thermaikos Basin (TheB, Fig. 1), two in the Prinos basin (PB, Fig. 1) and two in the Kavala Sub-Basin (KB, Fig 1). The stratigraphy for these wells is available in the literature (e.g. Martin 1987; Proedrou and Papaconstantinou 2004). Only the Thermaikos and Prinos Basins, that have been studied in detail (Gillet and Faugeres 1970; Faugeres and Robert 1976; Lyberis 1984; Martin 1987), are described here (Fig. 3). Proedrou and Sidiropoulos (1992) and Proedrou and Papaconstantinou (2004) thoroughly investigated the Prinos basin based on industry well data. The stratigraphy of the basins presented here is based on the integration of all these earlier works.

Four main seismic markers were identified in the Thermaikos and Prinos Basins using their well logs (Fig 3.): the seafloor (Top Quaternary), Top Upper Miocene, Top Lower Miocene, Top Pre-Miocene or the top of the acoustic basement (a.o. Martin, 1987; Lykousis et al., 2002; Proedrou and Papaconstantinou, 2004). The markers divide the seismic images into different units that can be distinguished by their unconformities and seismic character. 
Pliocene-Quaternary Unit: SU 1. The first seismic unit (SU 1) is Pliocene-Quaternary in age. In the Thermaikos Basin (Fig 3a), the unit consists of lacustrine, continental and floodplain deposits. Here, the seismic facies is continuous, with high amplitude and low frequency reflections. Prograding features can be distinguished. They correlate with alternating floodplain clays, silts and coarser sheets of fluvial sandstones and conglomerates corresponding only to the topsets of a prograding system. In the Prinos Basin (Fig 3b), there are two major prograding sequences (SU 1a and 1b), characterized by continuous low amplitude reflections at the base, whereas rather continuous horizontal reflectors alternating with bright reflectors are present at the top of the unit. These two sequences are also visible in the corresponding sedimentary succession, composed of offshore to shallow marine siliciclastic facies, capped by fluvial to littoral conglomerates that correspond to the topset of a prograding system. The alternating character of the seismic response may be associated with the alternation of coal deposits and siliciclastic facies (Proedrou and Papaconstantinou, 2004), deposited upstream of a typical large-scale Gilbert-delta, whose architecture is clearly visible in the seismic lines (Fig 4a).

Uppermost Miocene Unit: SU 2. The second unit (SU 2) is upper Miocene in age (mostly Messinian) and is separated from the Pliocene-Quaternary unit (SU 1) by a large unconformity. In the Thermaikos Basin, the seismic facies of the unit is poorly continuous with rapid lateral changes and internal unconformity (Fig 3a). It can thus be divided into two sub-units SU 2a and SU 2b. The deepest unit, SU 2a, consists of high frequency and high amplitude reflections that are more continuous upwards. According to the well description (Faugeres and Robert 1976; Lyberis 1984; Martin 1987), the base of this sub-unit (SU 2a, Fig 3a) consists of floodplain and fluvial deposits progressively flooded by siliciclastic-dominated shallow marine facies and marine platform carbonates higher up (Gillet and Faugeres, 1970; 
Faugeres and Robert,1976; Lalechos and Savoyat,1979). SU 2b (Fig. 3a) is characterized by poorly continuous, low frequency and high amplitude reflections, corresponding to floodplain and fluvial facies. In the Prinos Basin (Fig 3b), the seismic pattern is not as clear as in the Thermaikos Basin. Neither unconformity between SU1 and SU2 nor internal unconformities in SU 2 are clearly visible. The lower part of SU 2 is dominated by siliciclastic lacustrine and continental deposits, gradually changing to evaporitic and lacustrine siliciclastic deposits in the upper part. High amplitude, very continuous reflections characterize this unit. Bright, high amplitude reflections are most likely related to the evaporite layers. In this basin, SU 2 is Messinian.

The vertical evolution of the SU 2 facies combining the two basins suggests gentle basin deepening (SU 2a) at the onset of the unit formation, which is abruptly interrupted by a renewed continental sedimentation (floodplain and fluvial deposits, SU 2b) rapidly filling the accommodation space. The top of SU 2 is characterized by a major angular and erosional unconformity. We assume this erosional surface to be coeval with the Messinian Salinity Crisis (MSC) (Bache et al., 2012; Gorini et al., 2015).

Lower-middle Miocene Unit: SU 3. The third unit, SU 3, has been identified as early to middle Miocene (Gillet and Faugeres, 1970; Faugeres and Robert, 1976; Lalechos and Savoyat, 1979; Martin, 1987). The transition between SU 2 and SU 3 is illustrated by a sharp change in sedimentological and seismic facies (Fig 3a and 3b) from deep marine (SU 3) to continental (SU 2). In the Thermaikos Basin (Fig 3a), SU 3 consists of a platform of carbonates gradually evolving upward into offshore marine deposits. The seismic facies is characterized by high amplitude and continuous reflections. In the Prinos Basin, SU 3 consists of a continental succession at the base that changes gradually upward from deep to shallow marine facies (both siliciclastic and carbonates). This facies is capped by a thick, upward 
coarsening Tortonian turbidite sequence (Proedrou and Papaconstantinou, 2004). The vertical succession suggests basin deepening. The seismic facies of SU 3 is characterized by low frequency reflections. A large planar discontinuity cross cuts the lower-middle Miocene Unit at 2.5 s TWT (Proedrou and Papaconstantinou, 2004) (dashed red line in Fig. 3b). This surface is interpreted as a low-angle, nearly horizontal fault covered by basal salt. The salt has been drilled (Proedrou and Papaconstantinou, 2004). The presence of salt likely explains the decrease of seismic resolution below this surface in the Prinos Basin.

Pre-Miocene Unit: SU 4. In the Thermaikos Basin, a major unconformity separates SU 3 from the underlying fourth unit (SU 4), which has been interpreted as Late Oligocene (Faugeres and Robert, 1976). This unconformity is not visible in the Prinos Basin. It consists of a large package of continental conglomeratic deposits whose base has not been reached. No sharp transition announcing the acoustic basement is visible on the seismic line. The corresponding seismic signature for this unit consists of high amplitude, discontinuous reflections. The Oligocene and Eocene successions observed onshore are also visible in SU 4.

Basement Unit: SU 5. The fifth unit (SU 5) corresponds to the acoustic basement. Its seismic signature is transparent but no base is visible. The metamorphic Mesozoic rocks observed onshore are associated with this unit. However, no well to which we have access has been drilled this deep, as a result, no stratigraphic details can be provided for this unit.

\section{Seismic stratigraphy and structure of the North Aegean basins}

Four seismic reflection profiles were used to study the three deepest basins of the northern Aegean Sea: 1) two for the North Aegean Trough (NAT) (Fig. 4 and Fig. 5), 2) one for the North Skyros Basin (NSB) (Fig. 6) and 3) one for the Ikaria Basin (IB) (Fig. 7). Each 
of these figures shows the different seismic units and the major structures. The bottom line gives a final interpretation at a 1:1 scale.

The seismic signature of the deep basins was compared with those of the Thermaikos and Prinos Basins (Fig. 3) in order to identify the different seismic units (seismic extractions; Fig. 2) and to better constrain the stratigraphic ages of the seismic units in the deepest basins of the Aegean Sea.

\subsection{North Aegean Trough (NAT)}

With a maximum water depth of 1,610 m (Papanikolaou et al., 2002), the North Aegean Trough is the deepest seafloor depression in the northern Aegean Sea. It appears as an elongated basin with two parallel bathymetric slopes oriented NE-SW (Fig.1). The SW termination, which corresponds to the deepest part of the basin, is controlled by a horsetail faulting pattern. The NE part shows a bathymetric high. The two profiles analyzed (Fig. 4 and Fig. 5) are located on the northeastern edge (line 1 Fig. 1) and in the central part of the basin (line 2, Fig 1). They both show an asymmetrical basin structure with a slightly steeper slope on the southeastern side. The basin borders are controlled by steeply dipping faults with normal offset components (Martin, 1987; Mascle and Martin, 1990). A major WNW-ESEtrending normal fault, belonging to the above mentioned horsetail pattern, is imaged down to a depth of $10 \mathrm{~km}$ cross-cutting Quaternary deposits (Laigle et al. 2000).

Stratigraphy. Five seismic stratigraphic units can be distinguished. Two clear unconformities separate seismic unit SU 1 from SU 2 and SU 2 from SU 3. These seismic units correspond to those described in section 3.2. The unconformity between SU 1 and SU 2 is dated to the upper Miocene/Pliocene-Quaternary, whereas the unconformity between SU 2 and SU 3 is dated to the upper Miocene/middle-lower Miocene. The relative age of SU 1 is 
therefore Pliocene-Quaternary, of SU 2 uppermost Miocene (Messinian) and SU 3 early Miocene to Tortonian.

The thickness of SU 1 varies between $0.5 \mathrm{~s}$ in the NAT to more than $1.5 \mathrm{~s}$ on the adjacent shelf, resulting from drainage from the Dacic Basin (Suc et al., 2015). The major characteristic of SU 1, to the NE of line $1 \mathrm{~b}$ (Fig. 4), is a thick prograding unit, which is formed coeval with the prograding Pliocene-Quaternary unit observed in the Prinos Basin (see section 3.2). This progradation suggests a net increase of the sedimentary flux in this area around 5 Ma. Related clinoforms extend basinward (towards the SW on line 1b; Fig. 4) (Lykousis et al. 2002) (Fig. 3). The clinoform facies is correlated with rather continuous reflections on the southwestern side of line $1 \mathrm{~b}$ (Fig. 4) in the bathymetrically deepest part of the trough. In line 1a, weakly continuous reflections at the base of the unit, correlate with SU 1.

The unconformity separating SU 1 and SU 2 (see section 3.2) is visible in the NAT (Fig. 4 and 5). In the bathymetrically deepest part of line 1 (Fig. 4) and line 2 (Fig. 5), a local unconformity is visible within the SU 2 unit, separating SU 2a and SU 2b. In contrast with SU 1, the SU $2 \mathrm{a}$ facies are characterized by a high-amplitude medium-frequency seismic signature, consisting of an alteration of continuous and chaotic (channels?) reflections. SU $2 b$ onlaps SU 2a, indicating that the large wavelength low amplitude anticline affecting the SU 2a was active during the Late Miocene. The characteristic sharp reflections related to Messinian evaporites that occur elsewhere in the Aegean (e.g. the Prinos Basin, Proedrou and Sidiropoulos, 1992) are not visible here.

The thickness of SU 3 varies between less than $0.5 \mathrm{~s}$ and $2 \mathrm{~s}$ TWT. The top SU 3 consists of high amplitude and rather continuous reflections. The base of the unit is characterized by less continuous reflections and cannot be clearly identified in the thicker parts of the unit (e.g. to the SW of line 1b; Fig. 4). 
The deepest seismic units are SU 4 and SU 5 that cannot be constrained directly with well data. The maximum thickness of SU 4 is approximately $0.5 \mathrm{~s}$ TWT, whereas SU 5 is defined as the acoustic basement of the North Aegean Trough. High-amplitude discontinuous reflections characterize SU 4. They are clearly prograding in line 1b (Fig. 4). We interpret this facies as an alluvial like that described at the base of the Thermaikos Basin (see section 3.2). SU 4 and SU 5 are therefore dated to the Pre-Miocene/Oligocene. Unfortunately, the generally poor quality of the seismic data makes it very difficult to define internal facies in more detail.

Structure. Line 1a shows a large pop-up structure (Medusa structure; Fig. 4) that corresponds to a dextral strike-slip fault zone related to the North Anatolian Fault (Mascle and Martin 1990; Roussos and Lyssimachou 1991). SU 1 is thicker to the NW of the pop-up structure compared to the SE of the pop-up structure. SU 2 does not have this difference in thickness on both sides of the structure. This shows that the fault zone is asymmetrical and became active during the deposition of SU 1 and post SU 2. Older units do not show the same type of asymmetry. Smaller pop-up structures are visible down to 1.5 seconds TWT to the northwest of the line (Fig. 4). Large wavelength low-amplitude anticlines and synclines affect the younger sedimentary layer and even the seafloor, indicating that this strike-slip fault system is recent. Deeper steeply dipping normal faults, located between 2.5 to 3.5 seconds TWT, affect the lower sedimentary units up to the bottom of the Upper Miocene.

To the NE of line 1b, the deposition of SU 3 and SU 4 is controlled by a large border fault that does not affect the younger SU 1 and SU 2 units. Consequently this fault was active up to the Late Miocene.

Line 2 (Fig. 5), illustrates the southwestern end of the NAT where E-W to WNW-ESE normal faults (observed from bathymetry, Fig. 1) display a horsetail pattern. Eastward these 
normal faults are connected to the major NE-SW trending fault that bound the basin to the SE. This normal fault pattern inside the basin indicates a NS direction of stretching and a dextral strike-slip shear component along the NE-SW border fault. Seismic geometries and facies of SU 1 suggest that accommodation space was controlled by the strike-slip and extensional fault system (Fig. 5) in the deeper NAT.

\subsection{North Skyros Basin (NSB):}

The North Skyros Basin (NSB) is oriented NE-SW (Fig. 1) with a shape and structure comparable to that of the NAT - i.e. E-W to WNW-ESE oriented normal faults connected to a major NE-SW trending transtensional fault with a dextral strike-slip component. However, the basin asymmetry is less pronounced. The seismic profile (Fig. 6) is made of two mutually perpendicular lines: lines $3 a$ and $b$ trending NE-SW and NW-SE (line 3, Fig. 1). The lines show both the long and short axes of the basin.

Stratigraphy. Three seismic units were identified: SU 1, SU 2 and SU 3. Their seismic signatures are similar to the ones of the NAT. Therefore, we suggest that SU 1 is PlioceneQuaternary, SU 2 latest Miocene and SU 3 early Miocene to Tortonian. Pronounced internal unconformities in units and between units were visible.

SU 1 can be divided in SU 1a and SU $1 \mathrm{~b}$ and varies in thickness between $0.5 \mathrm{~s}$ on the shelf and $1.5 \mathrm{~s}$ TWT in the deep basin, significantly more than in the NAT. SU 1a is characterized by a transparent facies, also visible at the base of SU1 in the Thermaikos Basin, and SU 1 b by continuous high-amplitude high-frequency reflections.

SU 2 ranges in thickness from less than $0.5 \mathrm{~s}$ to $1.0 \mathrm{~s}$ TWT, which is comparable to the thicknesses observed in the NAT. One clear internal unconformity is visible in the basin. In the deep basin, high amplitude medium frequency reflections are visible at the base of SU 2 . 
This can be correlated with the SU 2a facies in the Thermaikos basin. SU $2 b$ consists in discontinuous low amplitude reflections that become more continuous upward.

In the whole NAT, chaotic seismic facies are associated with SU 3 and SU 4 and were interpreted as equivalents of marine and fluvial/floodplain deposits respectively. However, this chaotic seismic sequence is not visible in the North Skyros and Ikaria Basins. SU 3 and SU 4 are apparently lacking and deposition occurred later. For this reason, SU 5 is the deepest unit observed in the North Skyros Basin. It corresponds to the acoustic basement with a rather poor image quality.

Structure. Along line 3a (trending NE-SW) the two basin margins dip gently basinward. The borders of the basin are controlled by steeply dipping normal faults. Along line $3 b$ (trending NW-SE), the southern border of the basin is a nearly vertical dextral strikeslip fault with a dip-slip offset component. The combination of normal faults and dextral-slip faults define the transtensional pattern of the NSB (already identified by Mascle and Martin, 1990)

In various spots, growth structures are associated with the faults and anticlines and synclines are visible close to the seafloor, indicating recent activity. No compressional structures, such as the Medusa structure, are visible.

\subsection{Ikaria Basin(IB)}

The Ikaria Basin is the deepest basin in the southern part of the northern Aegean domain with a maximum depth of 1,400 m (Smith and Sandwell, 1997). It has a somewhat circular geometry (Fig. 1). The only available seismic line imaging the southwestern margin (Fig 7.)

of this basin is oriented ENE-WSW (line 4, Fig 1.). Its quality is poor and multiples are 
abundant. Observations are difficult to make below $2.0 \mathrm{~s}$ TWT. Still, the assessment of the stratigraphy and structure of the Ikaria Basin is based on this bit of seismic line.

Stratigraphy. Three seismic units can be identified based on the units described in section 3.2: SU 1, SU 2 and SU 5. SU 3 and SU 4 are apparently lacking. This interpretation is based on the absence of the chaotic character of SU 3 and SU 4 observed in the NAT. Furthermore, Tortonian aged middle Miocene sediments (SU 3) are the oldest sediments recognized in the southern onshore basins of Samos (Deschamps et al., 2013) and the Menderes grabens (Turgut and Eseller 2000). By analogy, one would therefore expect to find similarly aged sediments in the offshore Ikaria Basin.

The unconformity separating SU 1 and SU 2 is less clear than in the previously described basins. The unconformity separating SU 2 and SU 5 is well established. SU 1 correlates with Pliocene-Quaternary sediments, SU 2 to upper Miocene, and SU 5 to the acoustic basement.

The thickness of SU 1 ranges between $0.5 \mathrm{~s}$ and $1.0 \mathrm{~s}$ TWT. The top of SU 1 consists of high amplitude, discontinuous reflections. A possible unconformity is visible on the eastern side of the line, separating SU 1 in SU 1a and SU 1b. A shallow transparent base, $1.0 \mathrm{~s}$ TWT can be recognized to the west of line 4, which could correspond to the unconformity separating SU 1 from SU 5. Between offset 20.000 and 30.000, a chaotic seismic signature makes it impossible to identify the different seismic units (channel?). The quality of the seismic line is not good enough to describe any other seismic geometries.

SU 2 is thinner and less widespread than in the northern basins, only reaching $0.75 \mathrm{~s}$ TWT in the bathymetrically deepest part of the basin. Beyond the high amplitude, medium frequency and chaotic seismic characteristic, no internal architectures can be recognized in this unit. 
The transparent character of SU 5, corresponding to the acoustic basement, is visible directly below both SU 1 (on the western side of line 4, Fig. 7) and SU 2 (toward the east on line 4, Fig. 7). This implies a large hiatus and a younger deposition of sediments than in the NAT.

Structures. The most prominent feature on this line is located on the very eastern side of line 4 (Fig. 7) where tilted fault blocks affect the basin infill. Kilometer-scale "en-echelon" folds that also affect the seafloor on this vertical line extend westwards from these tilted fault blocks, suggesting recent/active basin formation. On the western side of line 4, large, dextral, transtensional faults that strongly affect SU 1, also imply present-day activity (Sakellariou et al., 2013).

\section{Discussion: Dynamics of Neogene basin development in the northern Aegean Sea}

\subsection{The two stages of Aegean extension}

Extension in the Aegean region has been driven by slab rollback since $45 \mathrm{Ma}$ (Brun and Sokoutis, 2010) and occurred in two main stages (Philippon et al., 2014; Brun et al., 2015;) with dextral rotation around a pole located at Scutary-Peç, Albania (Kissel and Laj, 1988) (Fig 8a). From the well-correlation the timing of subsidence has been determined (Fig. 8b). Only in the basins in the north of the North Aegean Sea Paleogene deposits have been found. Neogene deposits have been found throughout the region.

From the middle Eocene to the middle Miocene, extension is accommodated by localized deformation leading to i) the exhumation of high-pressure metamorphic rocks from the mantle to crustal depths, ii) the exhumation of high-temperature rocks in core complexes and iii) the deposition of Paleogene sedimentary basins (Fig. 8). In the North Aegean region, 
the most prominent basins are those of Thermaikos-NAT, Lemnos, Saros and Thrace (referred to as TheB, NAT, Lm, SB and ThrB, respectively, in Fig. 1).

Since the middle Miocene, extension is distributed over the whole Aegean domain enabling the widespread development of Neogene sedimentary basins both offshore and onshore (Figs. 8). Sedimentation started in these basins during the middle Miocene (e.g. Prinos, Thassos; P1 and Th in Fig. 1) or the late Miocene (e.g. Samos; Sa in Fig. 1). The deeper offshore basins of the North Aegean region are associated with dextral strike-slip fault zones (NAT-NAF, SEF, PLF in Fig.1) that are still active, as shown by earthquakes in their vicinity. Fault plane solutions are dominated by strike-slip type and seldom by normal fault type (Taymaz et al., 1991; Hatzfeld et al., 1999; Goldsworthy et al., 2002; Kiratzi and Louvari, 2003; Sakellariou et al., 2013).

The 3D restoration of the two-stage evolution at the scale of the Aegean region shows that the rate of trench retreat was around $0.6 \mathrm{~cm} / \mathrm{y}$ during the first $30 \mathrm{My}$, from the middle Eocene to the middle Miocene, and then accelerated up to $3.2 \mathrm{~cm} / \mathrm{y}$ during the last $13 \mathrm{My}$ (Brun et al., 2016, 2015). This trench retreat accelerated first by a factor 2 after Middle Miocene and then by a factor 5 after Pliocene, and was very likely responsible for the observed change in the mode of extension, from localized (i.e. core complexes) to distributed (i.e. widespread development of Neogene basins at the scale of the whole Aegean).

\subsection{The North Aegean Trough: a sinistral transtensional structure during the Paleogene}

To the west of the Saros Basin (Fig.1), the NAF takes a NE-SW direction and joins the SW-NE-trending North Aegean Trough (NAT) (Lyberis, 1984; Koukouvelas and Aydin, 2002), which controls the major bathymetric depression of the northern Aegean Sea (Papanikolaou et al. 2002). In the junction area between the NAT and the NAF, positive flower structures (e.g. Medusa structure; Fig. 4) suggest the reactivation of pre-existing faults 
of the NAT at the propagating tip of the NAF. This structure happens along the Athos Fault Zone (AFZ, Fig. 1) that developed into a dextral strike-slip faults along a pre-existing normal fault (Roussos and Lyssimachou, 1991). This is in agreement i) with the interpretation of the NAT as a structure initiated in the Paleogene to laterally accommodate the $30^{\circ}$ dextral rotation of the Chalkidiki block in sinistral transtension during the exhumation of the Southern Rhodope Core Complex (Brun and Sokoutis, 2007; Kydonakis et al., 2015) and ii) the presence of Neogene sediments in the extensional Thermaikos Basin (Fig. 3), which is connected to the NAT at its southwestern termination (NW end of line 2, Fig. 5).

\subsection{Basin record of Neogene dextral transtension}

All basins in the North Aegean region that are still active are characterized by transtensional fault patterns that combine dextral strike-slip faults trending NE-SW and sinistral strike-slip faults (Ganas et al., 2005) and normal faults dominantly trending NW-SE, as illustrated by the bathymetric map (Fig. 1) and by field observations in related islands (Koukouvelas and Aydin, 2002; Chatzipetros et al., 2013). These dextral strike-slip fault zones controlled thick sediment deposition from Late Miocene (SU2) to Pliocene-Quaternary (SU1) in the deep basins of the North Aegean: NAT, North Skyros Basin and Ikaria Basin (Fig. 4, Fig. 5, Fig. 6 and Fig. 7). The age of the deepest sediments in the Northern Skyros and Ikaria Basins (base SU 2) cannot be constrained precisely, but based on the previously described onshore stratigraphic and offshore structural observations, we ascribe them only to the middle Miocene and younger.

To the south, the Myrtoon-Ikaria Fault (MIF) (Philippon et al., 2012, 2014) cuts through the Cyclades in their middle part, connecting the Ikaria Basin (IB in Fig. 1) to the Myrtoon Basin (MB, Fig 1). The Ikaria Basin is bound by the islands of Ikaria to the south and Samos to the east. The sediments in the basin remnant that outcrops in Samos are 
Langhian/Tortonian (Weidmann et al., 1984; Koufos et al., 2009; Deschamps et al., 2013). The MIF is the offshore extension of the onshore Ismir-Balikeshir transfer zone (IBTZ; Fig. 1) ( Sözbilir et al., 2011; Ersoy et al., 2012; Uzel et al., 2013). Lower-upper Miocene sedimentary-volcanic sediments were deposited in basins in this transtensional corridor, located at the northwestern border of the Menderes Massif (Ersoy et al., 2012). Simultaneously, grabens developed in the Menderes, accommodating a NE-SW stretching direction. Extending over $450 \mathrm{~km}$, from Myrtoon Basin to Balikeshir (Fig 1.), this dextral strike-slip fault zone was then active after the middle Miocene around $10 \mathrm{My}$ before the arrival of the NAT in the North Aegean (Armijo et al., 1999). The lack of direct markers makes it difficult to identify when displacements ceased on this fault. According to some studies the fault became inactive during the Early Pliocene (Walcott and White, 1998). This would coincide with the assumption that it was in the Pliocene-Pleistocene when the NAF fully localized, reaching the North Aegean, in agreement with the last exhumation ages recorded by low-temperature thermochronology in the Cyclades islands (see review in Philippon et al., 2012).

To the north, the connection between the NAF and the NAT led to the development of a dense set of normal faults trending E-W to NE-SW branching on the main linear eastern border of the NAT (Fig. 1). This transtensional pattern, with a dextral strike-slip component along the NAT trend, resulted from the reactivation by N-S stretching of a pre-existing fault zone trending NE-SW. Kinematic analysis of fault systems in the northern Aegean Sea (Lyberis, 1984; Lyberis and Sauvage, 1985; Mercier et al., 1989) revealed that a change in the direction of stretching from NE-SW to N-S occurred in the Lower Pleistocene, suggesting that the present-day displacement pattern related to the propagation of the NAF in the North Aegean region was established rather recently, in the lower-middle Pleistocene. In agreement with this hypothesis, the positive flower structure visible to the north of the NAT (Medusa 
structure; Fig.4) mainly affects Pliocene-Quaternary sediments above the late Miocene angular and erosional unconformity that is directly related to the Messinian Salinity Crisis, as evidenced by the presence of evaporite deposits in the Prinos and Orfanos Basins (Suc et al., 2015).

In sum, the present study shows that i) Neogene basins recorded the initiation of dextral transtension in the central Aegean (Myrtoon-Ikaria Fault) in the Langhlian-Tortonian (i.e. in the range 16-8 Ma, in agreement with the distribution of LT-thermochronological ages in the Cyclades (see Philippon et al., 2012)) and ii) deformation then migrated northward up to the NAF, which propagated westward toward the NAT in the Pliocene-Pleistocene.

\subsection{Geodynamic implications}

After 30 My of localized deformation was dominated by the development of core complexes, the widespread development of Neogene basins during the last $13 \mathrm{Ma}$ at the scale of the whole Aegean region (a range of more than 1,000 km from Crete to Rhodope), most likely resulted from an acceleration of trench retreat (Brun et al., 2015). It is noteworthy that the offshore Neogene basins of the northern Aegean Sea, since their onset, developed in dextral transtension. This shows that Anatolia started to displace westward at almost the same time as the acceleration of trench retreat and, consequently suggests that the two effects likely have the same cause or result from mutually dependant mechanisms.

Recent tomographic models of the Aegean-Anatolia mantle (e.g. Salaün et al., 2012) show that the Hellenic slab is torn below western Anatolia. The slab tear is geometrically related to the domain of the strongest Aegean extension during the Neogene. It is the most likely cause of the observed acceleration.

\section{Conclusions}


Our work can be summarized as follows:

(1) A stratigraphic synthesis of the North Aegean Tertiary basins was generated using published studies on basins, most onshore and a few offshore, and eight well logs. The study area shows two sharp unconformities that correspond to the Eocene-Oligocene transition and the Miocene-Pliocene shift. These discontinuities were used as marker horizons for a more detailed structural and seismic stratigraphic interpretation resulting in the identification of several seismic units. A general seismic signature chart was established using onshore basin stratigraphy and well data, which was then used to constrain the ages of the different seismic units.

(2) The relation between structure and stratigraphic record was studied in three deep basins of the north Aegean: i) the North Aegean Trough, ii) the northern Skyros Basin and iii) the Ikaria Basin, using bathymetric data, a 2D seismic dataset acquired in the 1970s and the well-investigated stratigraphic records of the onshore deep basins. The structure and stratigraphic record shows that the three basins are characterized by a transtensional tectonic regime, controlled by NE-SW trending dextral strike-slip faults. The oldest LanghlianTortonian deposits in the North Skyros Basin and in the Ikaria Basin show that they started in the middle-late Miocene. The North Aegean Trough-Thermaikos Basin system has a more complicated tectonic history in two main stages. Sedimentation started in the Eocene, likely related to a NNE-SSW trending sinistral strike-slip fault belt that laterally accommodated the exhumation of the Southern Rhodope Core Complex. This early structure was reactivated with a dextral strike-slip component during the Pleistocene when the North Anatolian Fault propagated westward.

(3) During the extension of the Aegean region driven by the Hellenic slab rollback since the middle Eocene, the widespread development of Neogene basins at the scale of the 
whole Aegean domain attests to a major tectonic change due to the acceleration of trench retreat in the middle Miocene. Our study shows that, to the south of the North Aegean Fault and to the east of the North Aegean Trough, all Neogene basins developed i) in transtension and ii) with a northward migration of the associated NE-SW trending strike-slip faults, from the Myrtoon-Ikaria Fault in the south (i.e. in the Cyclades) to the North Anatolian Fault in the north. At regional scale, this tectonic pattern indicates that the westward escape of Anatolia started to interact with trench retreat in the middle Miocene, around $10 \mathrm{Myr}$ before the arrival of the North Anatolian Fault in the North Aegean region.

\section{Acknowledgments}

This work has been funded by a 'Bourse d' Excellence Descartes' of the French Government (attributed to Anouk Beniest). We are indebted to Sebastien Rohais, IFP Energies Nouvelles, and Total for providing us material to construct a synthetic seismic and wells database. We thank Jean-Pierre Suc for fruitful discussions and valuable insights. We also would like to express our gratitude to two anonymous reviewers who provided us with very constructive comments and suggestions.

\section{References}

Armijo, R., Meyer, B., Hubert, A., Barka, A., 1999. Westward propagation of North Anatolian fault into the northern Aegean:Timing and kinematics: Comment and Reply. Geology 27, 267-170. doi:10.1130/0091-7613(1999)027<0267:WPOTNA>2.3.CO;2

Bache, F., Popescu, S.M., Rabineau, M., Gorini, C., Suc, J.P., Clauzon, G., Olivet, J.L., Rubino, J.L., Melinte-Dobrinescu, M.C., Estrada, F., Londeix, L., Armijo, R., Meyer, B., Jolivet, L., Jouannic, G., Leroux, E., Aslanian, D., Reis, A.T. Dos, Mocochain, L., Dumurdžanov, N., Zagorchev, I., Lesić, V., Tomić, D., Namik Çağatay, M., Brun, J.P., 
Sokoutis, D., Csato, I., Ucarkus, G., Çakir, Z., 2012. A two-step process for the reflooding of the Mediterranean after the Messinian Salinity Crisis. Basin Res. 24, 125153. doi:10.1111/j.1365-2117.2011.00521.x

Brooks, M., Ferentinos, G., 1980. Structure and evolution of the Sporadhes Basin of the North Aegean Trough, northern Aegean Sea. Tectonophysics 68, 15-30.

Brun, J.-P., Faccenna, C., 2008. Exhumation of high-pressure rocks driven by slab rollback 272, 1-7. doi:10.1016/j.eps1.2008.02.038

Brun, J.-P., Faccenna, C., Gueydan, F., Sokoutis, D., Philippon, M., Kydonakis, K., Gorini, C., 2016. The two-stage Aegean extension, from localized to distributed, a result of slab rollback acceleration. Can. J. Earth Sci. in press.

Brun, J.-P., Gueydan, F., Kydonakis, K., Philippon, M., Sokoutis, D., Beniest, A., Gorini, C., 2015. The two-stage Aegean extension, slow-localized vs fast-distributed, in: European Geoscience Union General Assembly 2015.

Brun, J.-P., Sokoutis, D., 2010. 45 m.y. of Aegean crust and mantle flow driven by trench retreat. Geology 38, 815 - 818. doi:10.1130/G30950.1

Brun, J.-P., Sokoutis, D., 2007. Kinematics of the Southern Rhodope Core Complex. Int. J. Earth Sci. 96, 1079-1099. doi:10.1007/s00531-007-0174-2

Carbotte, S.M., Arko, R., Chayes, D.N., Haxby, W., Lehnert, K., O’Hara, S., Ryan, W.B.F., Weissel, R. a., Shipley, T., Gahagan, L., Johnson, K., Shank, T., 2004. New integrated data management system for Ridge2000 and MARGINS research. Eos, Trans. Am. Geophys. Union 85, 553. doi:10.1029/2004EO510002

Chatzipetros, A., Kiratzi, A., Sboras, S., Zouros, N., Pavlides, S., 2013. Tectonophysics Active faulting in the north-eastern Aegean Sea Islands. Tectonophysics 597-598, 106- 
122. doi:10.1016/j.tecto.2012.11.026

Coskun, B., 2000. North Anatolian Fault - Saros Gulf relationships and their relevance to hydrocarbon exploration, northern Aegean Sea, Turkey. Mar. Pet. Geol. 17, 751-772.

Deschamps, R., Hamon, Y., Darre, T., Gorini, C., 2013. Caractérisation des séries lacustres du Miocène Supérieur de l'Ile de Samos. Un exemple de paléolac alcalin et salin, in: Congrès de L'Association Des Sédimentologistes Français, Paris, France.

Dewey, J.F., Sengör, A.M.C., 1979. Aegean and surrounding regions: complex multiplate and continuum tectonics in a convergent zone. Geol. Soc. Am. Bull. 90, 84 - 92.

Elmas, N., Bentli, I., 2013. Environmental and depositional characteristics of diatomite deposit, Alayunt Neogene Basin ( Kutahya ), West Anatolia, Turkey 395-412. doi:10.1007/s12665-012-1745-5

Ersoy, E.Y., Çemen, İ., Helvac1, C., Billor, Z., 2014. Tectono-stratigraphy of the Neogene basins in Western Turkey: Implications for tectonic evolution of the Aegean Extended Region. Tectonophysics 635, 33-58. doi:10.1016/j.tecto.2014.09.002

Ersoy, Y., Helvaci, C., Uysal, I., Karaoğlu, Ö., Palmer, M.R., Dindi, F., 2012. Petrogenesis of the Miocene volcanism along the Izmir-Balikesir Transfer Zone in western Anatolia, Turkey: Implications for origin and evolution of potassic volcanism in post-collisional areas. J. Volcanol. Geotherm. Res. 241-242, 21-38.

doi:10.1016/j.jvolgeores.2012.05.022

Faugeres, L., Robert, C., 1976. Etude sédimentologique et minéralogique de deux forages du Golfe Thermaïque (Mer Egée). Géologie Méditerrannée 3, 209 - 218.

Ferrière, J., Reynaud, J.-Y., Pavlopoulos, A., Bonneau, M., Migiros, G., Chanier, F., Proust, J.-N., Gardin, S., 2004. Geologic evolution and geodynamic controls of the Tertiary 
intramontane piggyback Meso-Hellenic basin, Greece. Bull. la Société Géologique Fr. 175, 361-381. doi:10.2113/175.4.361

Ganas, A., Drakatos, G., Pavlides, S.B., Stavrakakis, G.N., Ziazia, M., Sokos, E., Karastathis, V.K., 2005. The $2001 \mathrm{Mw}=6.4$ Skyros earthquake, conjugate strike-slip faulting and spatial variation in stress within the central Aegean Sea. J. Geodyn. 39, 61-77. doi:10.1016/j.jog.2004.09.001

Gillet, S., Faugeres, L., 1970. Contribution à l'étude de Pontien de Macédonie, analyse géologique et sédimentologique des dépots de Trilophos (SW de Salonique). Rev. Géography Phys. du Geol. Dyn. 2, 9 - 24.

Goldsworthy, M., Jackson, J., Haines, J., 2002. The continuity of active fault systems in Greece. Geophys. J. Int. 148, 596-618. doi:10.1046/j.1365-246X.2002.01609.x

Gorini, C., Montadert, L., Rabineau, M., 2015. New imaging of the salinity crisis: Dual Messinian lowstand megasequences recorded in the deep basin of both the eastern and western Mediterranean. Mar. Pet. Geol. doi:10.1016/j.marpetgeo.2015.01.009

Hatzfeld, D., Ziazia, M., Kementzetzidou, D., Hatzidimitriou, P., Panagiotopoulos, D., Makropoulos, K., Papadimitriou, P., Deschamps, a., 1999. Microseismicity and focal mechanisms at the western termination of the North Anatolian Fault and their implications for continental tectonics. Geophys. J. Int. 137, 891-908. doi:10.1046/j.1365-246X.1999.00851.x

Hollenstein, C., Müller, M.D., Geiger, a., Kahle, H.-G., 2008. Crustal motion and deformation in Greece from a decade of GPS measurements, 1993-2003. Tectonophysics 449, 17-40. doi:10.1016/j.tecto.2007.12.006

Hubert-Ferrari, A., King, G., Manighetti, I., Armijo, R., Meyer, B., Tapponnier, P., 2003. Long-term elasticity in the continental lithosphere; modelling the Aden Ridge 
propagation and the Anatolian extrusion process. Geophys. J. Int. 153, 111-132.

doi:10.1046/j.1365-246X.2003.01872.x

Islamoglu, Y., Harzhauser, M., Gross, M., Jimenez-Moreneo, G., Coric, S., Kroh, A., Rögl, F., van der Made, J., 2008. From Tethys to Eastern Paratethys: Oligocene depositional environments, paleoecology and paleobiogeography of the Thrace Basin (NW Turkey). Int. J. Earth Sci. 18.

Jolivet, L., Brun, J.-P., 2010. Cenozoic geodynamic evolution of the Aegean. Int. J. Earth Sci. 99, 109-138. doi:10.1007/s00531-008-0366-4

Kiratzi, A., Louvari, E., 2003. Focal mechanisms of shallow earthquakes in the Aegean Sea and the surrounding lands determined by waveform modelling: a new database. J. Geodyn. 36, 251-274. doi:10.1016/S0264-3707(03)00050-4

Kissel, C., Laj, C., 1988. The Tertiary geodynamic evolution of the Aegean Arc: a paleomagnetic reconstruction. Tectonophysics 146, 183-201.

Koufos, G.D., Kostopoulos, D.S., Vlachou, T.D., 2009. The Late Miocene Mammal Faunas of the Mytilinii Basin, Samos Island, Greece: New Collection 16. Biochronology. Beitrage zur Paläontologie 31, 397-408.

Koukouvelas, I.K., Aydin, A., 2002. Fault structure and related basins of the North Aegean Sea and its surroundings 21. doi:10.1029/2001TC901037

Kydonakis, K., Moulas, E., Chatzitheodoridis, E., Brun, J.-P., Kostopoulos, D., 2015. Firstreport on Mesozoic eclogite-facies metamorphism preceding Barrovian overprint from the western Rhodope (Chalkidiki, northern Greece). Lithos 220-223, 147-163. doi:10.1016/j.lithos.2015.02.007

Laigle, M., Hirn, a., Sachpazi, M., Roussos, N., 2000. North Aegean crustal deformation: An 
active fault imaged to $10 \mathrm{~km}$ depth by reflection seismic data. Geology 28, 71-74. doi:10.1130/0091-7613(2000)28<71:NACDAA>2.0.CO;2

Lalechos, N., Savoyat, E., 1979. La sédimentation néogène dans la Fosse Nord Égéen, in: Proceedings of the 6th Colloqium on the Aegean Region.

Le Pichon, X., Angelier, J., 1981. The Aegean Sea. Philos. Trans. R. Soceity London. Ser. A, Math. Phys. Sci. 300, 357-372. doi:10.1016/S0140-6736(02)54815-7

Lyberis, N., 1984. Tectonic evolution of the Northern Aegean Trough. Geol. Soc. London, Spec. Publ. 17, 709.

Lyberis, N., Sauvage, J., 1985. Evolution tectonique de la région nord égéenne (Grece) du Pliocene au Pleistocene. Bull. la Société géologique Fr. 1, 581-595.

Lykousis, V., 2009. Sea-level changes and shelf break prograding sequences during the last $400 \mathrm{ka}$ in the Aegean margins : Subsidence rates and palaeogeographic implications. Cont. Shelf Res. 29, 2037-2044. doi:10.1016/j.csr.2008.11.005

Lykousis, V., Anagnostou, C., Pavlakis, P., Rousakis, G., Alexandri, M., 1995. Quaternary sedimentary history and neotectonic evolution of the eastern part of Central Aegean Sea , Greece. Mar. Geol. 128, 59-71.

Lykousis, V., Karageorgis, A.P., Chronis, G.T., 2005. Delta progradation and sediment fluxes since the last glacial in the Thermaikos Gulf and the Sporades Basin, NW Aegean Sea, Greece. Mar. Geol. 223, 381-397. doi:10.1016/j.margeo.2005.06.026

Lykousis, V., Roussakis, G., Alexandri, M., Pavlakis, P., Papoulia, I., 2002. Sliding and regional slope stability in active margins : North Aegean Trough ( Mediterranean ). Mar. Geol. 186, $281-298$.

Martin, L., 1987. Structure et evolution recente de la mer Egee: apports d'une étude par 
sismique reflexion.

Mascle, J., Martin, L., 1990. Shallow structure and recent evolution of the Aegean Sea : A synthesis based on continuous reflection profiles. Mar. Geol. 94, 271-299.

McClusky, S., Balassanian, S., Barka, a., Demir, C., Ergintav, S., Georgiev, I., Gurkan, O., Hamburger, M., Hurst, K., Kahle, H., Kastens, K., Kekelidze, G., King, R., Kotzev, V., Lenk, O., Mahmoud, S., Mishin, a., Nadariya, M., Ouzounis, a., Paradissis, D., Peter, Y., Prilepin, M., Reilinger, R., Sanli, I., Seeger, H., Tealeb, a., Toksöz, M.N., Veis, G., 2000. Global Positioning System constraints on plate kinematics and dynamics in the eastern Mediterranean and Caucasus. J. Geophys. Res. 105, 5695. doi:10.1029/1999JB900351

McKenzie, D., 1972. Active Tectonics of the Mediterranean Region. Geophys. J. R. Astron. Soc. 30, 109-185. doi:10.1111/j.1365-246X.1972.tb02351.x

Melinte-Dobrinescu, M.C., Suc, J., Clauzon, G., Popescu, S.-M., Armijo, R., Meyer, B., Biltekin, D., Namik Çagatay, M., Ucarkus, G., Jouannic, G., Fauquette, S., Çakir, Z., 2009. The Messinian Salinity Crisis in the Dardanelles region : Chronostratigraphic constraints. Palaeogeogr. Palaeoclimatol. Palaeoecol. 278, 24-39. doi:10.1016/j.palaeo.2009.04.009

Mercier, J.L., Sorel, D., Vergely, P., Simeakis, K., 1989. Extensional tectonic regimes in the Aegeanbasins during the Cenozoic. Basin Res. 2, $49-71$.

Müller, M.D., Geiger, a., Kahle, H.G., Veis, G., Billiris, H., Paradissis, D., Felekis, S., 2013. Velocity and deformation fields in the North Aegean domain, Greece, and implications for fault kinematics, derived from GPS data 1993-2009. Tectonophysics 597-598, 34-49. doi:10.1016/j.tecto.2012.08.003

Nunn, J. a., Harris, N.B., 2007. Subsurface seepage of seawater across a barrier: a source of 
water and salt to peripheral salt basins. Bull. Geol. Soc. Am. 119, 1201-1217. doi:10.1130/B26088.1

Okay, A.I., Satir, M., Maluski, H., Siyako, M., Monie, P., Metzger, R., Akyüz, S., 1996. Paleo- and Neo-Tethyan events in the northwestern Turkey: Geologic and geochronologic constraints. Tecton. Evol. Asia 420 - 441.

Papanikolaou, D., Alexandri, M., Nomikou, P., Dionysois, B., 2002. Morphotectonic structure of the western part of the North Aegean Basin based on swath bathymetry. Mar. Geol. $190,465-492$.

Philippon, M., Brun, J., Gueydan, F., 2012. Deciphering subduction from exhumation in the segmented Cycladic Blueschist Unit (Central Aegean, Greece). Tectonophysics 524-525, 116-134. doi:10.1016/j.tecto.2011.12.025

Philippon, M., Brun, J., Gueydan, F., Sokoutis, D., 2014. The interaction between Aegean back-arc extension and Anatolia escape since Middle Miocene. Tectonophysics 631, 176 - 188. doi:10.1016/j.tecto.2014.04.039

Proedrou, P., Papaconstantinou, C.M., 2004. Prinos Basin - A model for oil exploration. Bull. Geol. Soc. Greece. Proc. 10th Int. Congr. Thessaloniki XXXVI, 327 - 333.

Proedrou, P., Sidiropoulos, T., 1992. Prinos Field-Greece Aegean Basin.

Roussos, N., Lyssimachou, T., 1991. Structure of the Central North Aegean Trough: an active strike-slip deformation zone. Basin Res. 3, 39 - 48.

Ryan, W.B.F., Carbotte, S.M., Coplan, J.O., O’Hara, S., Melkonian, A., Arko, R., Weissel, R.A., Ferrini, V., Goodwillie, A., Nitsche, F., Bonczkowski, J., Zemski, R., 2009. Global Multi-Resolution Topography synthesis. Geochemistry, Geophys. Geosystems 10. doi:10.1029/2008GC002332 
Sakellariou, D., Mascle, J., Lykousis, V., 2013. Strike Slip Tectonics and Transtensional Deformation in the Aegean Region and the Hellenic Arc : Preliminary Results. Bull. Geol. Soc. Greece XLVII, 647-656.

Salaün, G., Pedersen, H. a., Paul, A., Farra, V., Karabulut, H., Hatzfeld, D., Papazachos, C., Childs, D.M., Pequegnat, C., 2012. High-resolution surface wave tomography beneath the Aegean-Anatolia region: Constraints on upper-mantle structure. Geophys. J. Int. 190, 406-420. doi:10.1111/j.1365-246X.2012.05483.x

Schuster, J.M., Auxietre, J.L., Biju-Duval, B., Letouzey, J., 1987. CIDOG: Mer Egée/Mer de Crete. Rapport CFP-IFP.

Şengör, A.M.C., Tüysüz, O., İmren, C., Sakınç, M., Eyidoğan, H., Görür, N., Le Pichon, X., Rangin, C., 2005. the North Anatolian Fault: a New Look. Annu. Rev. Earth Planet. Sci. 33, 37-112. doi:10.1146/annurev.earth.32.101802.120415

Siyako, M., Huvaz, O., 2007. Eocene stratigraphic evolution of the Thrace Basin, Turkey. Sediment. Geol. 198, 75 - 91.

Smith, W.H., Sandwell, D.T., 1997. Global Sea Floor Topography from Satellite Altimetry and Ship Depth Soundings. Science (80-. ). 277, 1956-1962. doi:10.1126/science.277.5334.1956

Sözbilir, H., Sarı, B., Uzel, B., Sümer, Ö., Akkiraz, S., 2011. Tectonic implications of transtensional supradetachment basin development in an extension-parallel transfer zone: the Kocaçay Basin, western Anatolia, Turkey. Basin Res. 23, 423-448. doi:10.1111/j.1365-2117.2010.00496.x

Suc, J.-P., Popescu, S.-M., Do Couto, D., Clauzon, G., Rubino, J.-L., Melinte-Dobrinescu, M.C., Quillévéré, F., Brun, J.-P., Dumurdžanov, N., Zagorchev, I., Lesić, V., Tomić, D., Sokoutis, D., Meyer, B., Macaleţ, R., Rifelj, H., 2015. Marine gateway vs. fluvial stream 
within the Balkans from 6 to 5 Ma. Mar. Pet. Geol. 1-15.

doi:10.1016/j.marpetgeo.2015.01.003

Taymaz, T., Jackson, J., McKenzie, D., 1991. Active tectonics of the north and central Aegean Sea. Geophys. J. Int. 106, 433-490.

Turgut, S., Eseller, G., 2000. Sequence stratigraphy, tectonics and depositional history in eastern Thrace Basin, NW Turkey. Mar. Pet. Geol. 17, 61 - 100.

Uzel, B., Sözbilir, H., Özkaymak, Ç., Kaymakci, N., Langereis, C.G., 2013. Structural evidence for strike-slip deformation in the Izmir-Balikesir transfer zone and consequences for late Cenozoic evolution of western Anatolia (Turkey). J. Geodyn. 65, 94- 116. doi:10.1016/j.jog.2012.06.009

Walcott, C.R.Ł., White, S.H., 1998. Constraints on the kinematics of post-orogenic extension imposed by stretching lineations in the Aegean region. Tectonophysics 298, 155-175.

Weidmann, M., Solounias, N., Drake, R.E., Curtis, G.H., 1984. Neogene stratigraphy of the eastern basin, Samos Island, Greece. Geobios 17, 477-490. 


\section{Figure captions}

Figure 1. Regional map of the northern Aegean Sea highlighting the major structures. GMRT bathymetry data (Carbotte et al., 2004) highlight the deepest basins. Line locations are provided for the North Aegean Trough (Line 1a, 1b and 2), the Northern Skyros Basin (Line 3) and the Ikaria Basin (Line 4). Well-locations are provided for the Thermaikos Basin (ThC1) and the Prinos Basin (P1). The faults mapped are recovered from previous studies (Brun et al., 2016; Mascle and Martin, 1990) and where possible enhanced with the use of seismic data. Inactive faults are depicted with dashed lines. Abbreviations of basins, islands and geological features: AFZ: Athos Fault Zone; Chi: Chios; IB: Ikaria Basin; IBTZ: IzmirBalikeshir Transfer Zone; Ik: Ikaria;; Lb: Lesbos; Lm: Limnos; MB: Menderes Grabens; MiB: Mirthoon Basin; MIF: Mirthoon-Ikaria Fault; NAF: North Anatolian Fault; NAT: North Aegean Trough; NSB: North Skyros Basin; OB: Orfanos Basin; Pb: Prinos Basin; Sa: Samos;

SB: Saros Basin; SEF: Skyros-Eubea fault zone; Sk: Skyros; SM: Sea of Marmara; SRCC:

Southern Rhodope Core Complex; Th: Thassos; TheB: Thermaikos Basin; ThrB: Thrace Basin.

Figure 2. Well correlation based on the literature on offshore well log data and on literature on the onshore basin in the northern Aegean domain. Logs modified after Martin, (1987): A, B, C, F, G, Proedrou and Papaconstantinou, (2004): C, Coskun, (2009): H, Deschamps et al., (2012): K and (Turgut and Eseller, (2000): L. NAT: North Aegean Trough. NSB = Northern Skyros Basin. IB = Ikaria Basin.

Figure 3. Seismic lines with tied wells in A) Thermaikos Basin, Top Upper Miocene, Top Lower Miocene, Top pre-Miocene and an intra-SU2 horizon, were identified, and B) Prinos 
Basin, Top Upper Miocene, Top Lower Miocene, Top pre-Miocene and an intra-SU1 horizon were identified. An average velocity of $2500 \mathrm{~m} / \mathrm{s}$ was used to tie the wells to the seismic images.

Figure 4. Interpretation of two perpendicular lines, line 1a and line 1b, in the NE of the North Aegean Trough: A) structural and seismic stratigraphic analysis; B) final interpretation. SU 1a, SU 1b, SU 2a, SU 2b, SU 3, SU 4 and SU 5 are visible.

Figure 5. Interpretation of seismic line 2 in the SW of the North Aegean Trough: A) structural and seismic stratigraphic analysis; B) final interpretation. SU 1a, SU 1b, SU 2a, SU 2b, SU 3, SU 4 and SU 5 are visible.

Figure 6. Interpretation of two perpendicular lines, line 3a and line 3b, in the Northern Skyros Basin: A) structural and seismic stratigraphic analysis; B) final interpretation. SU 1a, SU 1b, SU 2a, SU $2 b$ and SU 5 are visible

Figure 7. Interpretation of seismic line 2 in the SW of the Ikaria Basin: A) structural and seismic stratigraphic analysis; B) final interpretation. SU 1a, SU 1b, SU 2a, SU 2b and SU 5 are visible.

Figure 8. Left: schematic reconstruction of the opening of the North Aegean basins, modified after Phillipon et al., 2012. Right: determination of the sediment thickness and timing per seismic based on the composite well-log (Fig. 2, Martin, (1987); Proedrou and Papaconstantinou, (2004); Coskun, (2009); Deschamps et al., (2012); Turgut and Eseller, (2000)). Creation of accommodation space started in the north of the northern Aegean Sea in 
during the Eocene. During the upper Miocene, accommodation space was generated in the whole northern Aegean domain. 


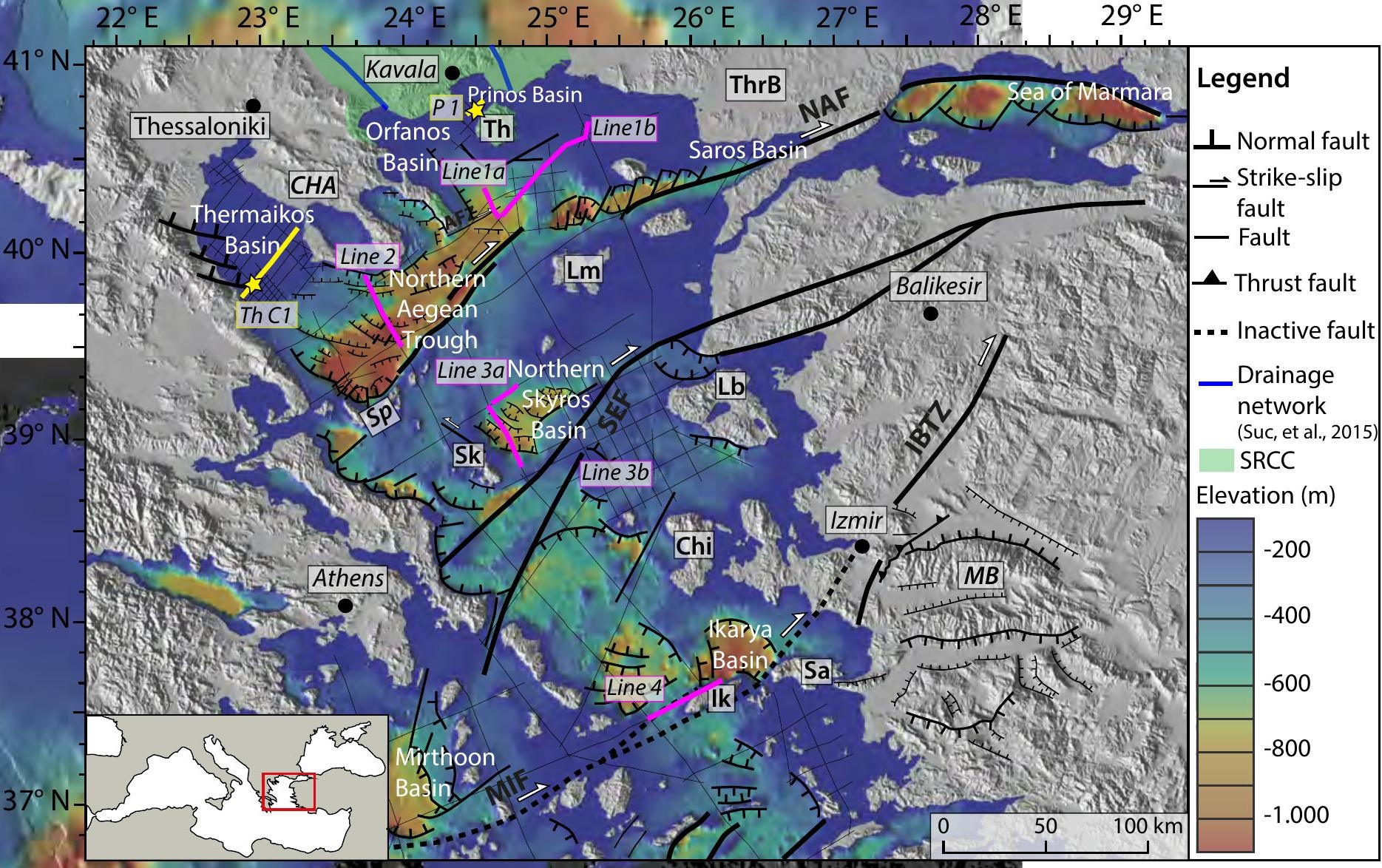




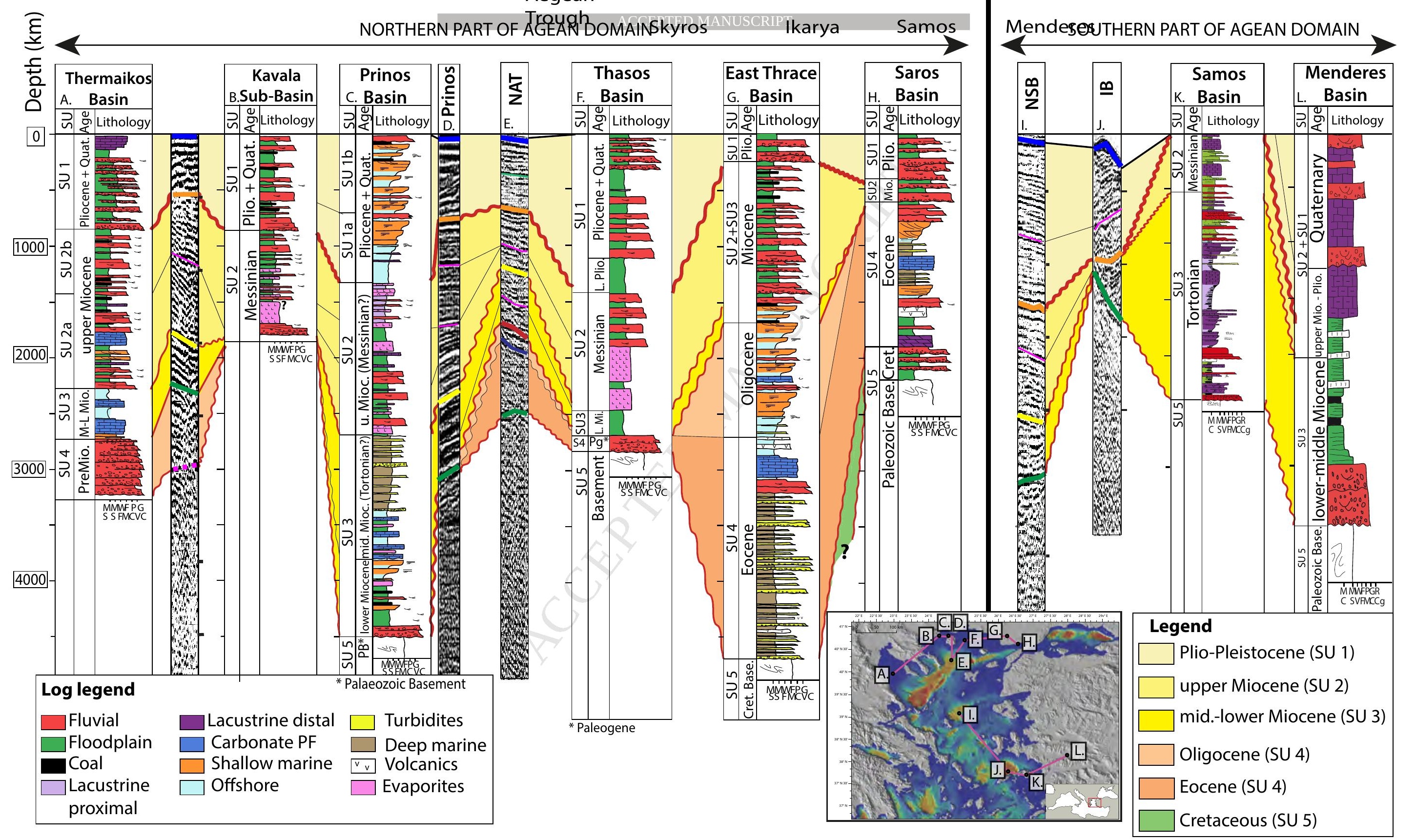




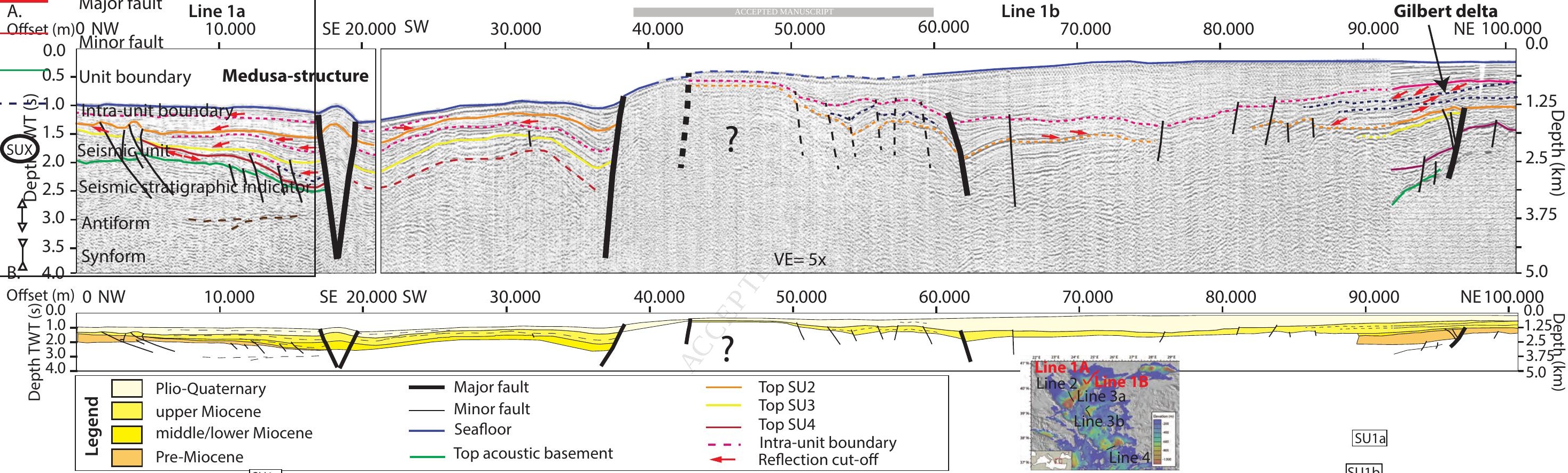




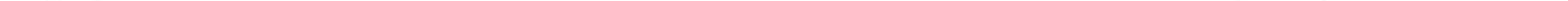




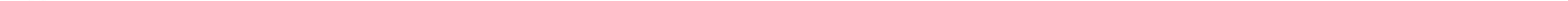


Northern Aegean Sea
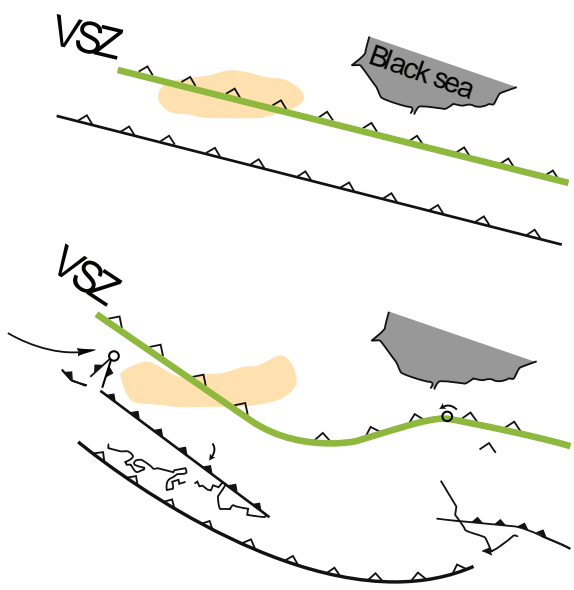

Sediment flux during Middle Miocene

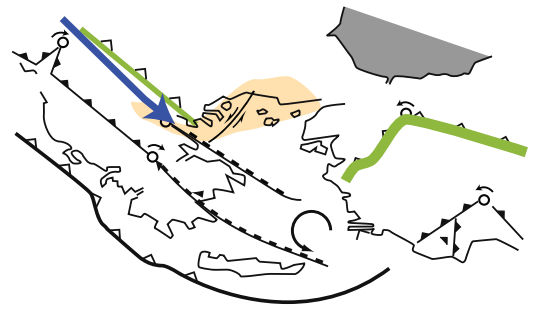

Sediment flux since Tortonian

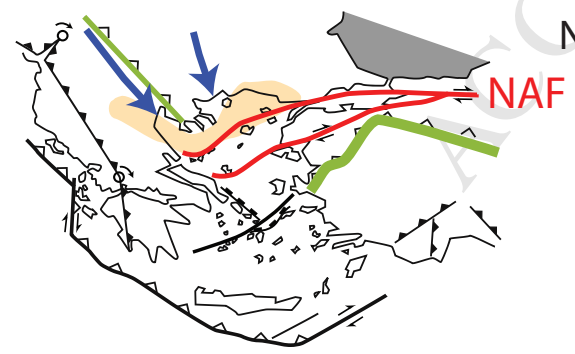

Location Paleogene basins

Middle-Miocene

ca. $13 \mathrm{Ma}$

\section{Formation} basins $\sqrt{ }$ $1000 \mathrm{~m}$ $1500 \mathrm{~m}$ $2000 \mathrm{~m}$
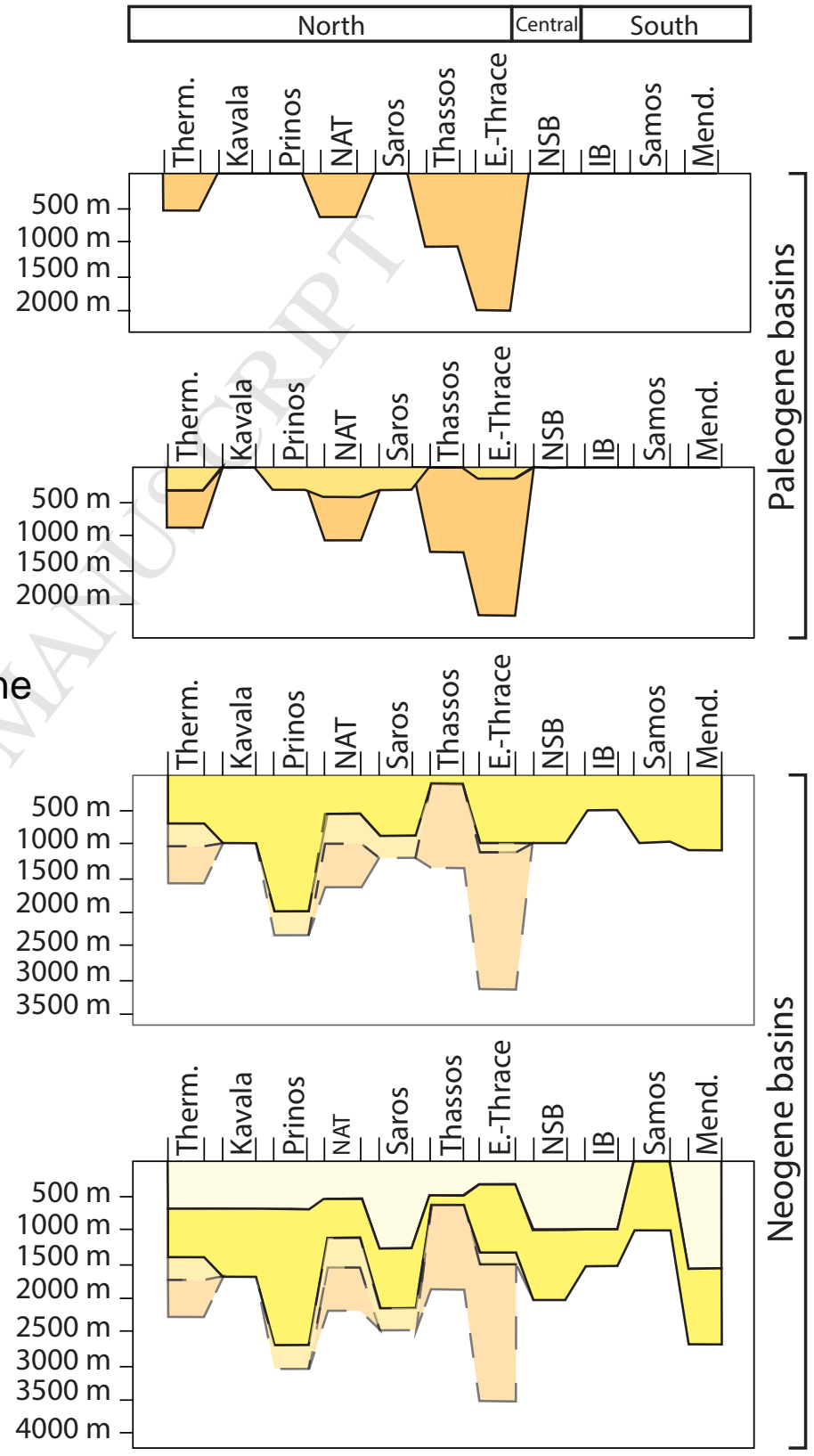